\title{
СКВАЖИННЫЕ МЕТОДЫ ДОБЫЧИ ПОЛЕЗНЫХ ИСКОПАЕМЫХ
}

\author{
НУРАНБАЕВА Б.М., АСАНОВ Т.Н. \\ Caspian University
}

\begin{abstract}
Аннотация: В научной статье предлагаются задачи поиска новых месторождений, полезных ископаемых и выявление их промышленного значения. Для выполнения упомянутых задач с высоким качеством и в сжатые сроки необходимо соответствующее техническое сопровождение геолого-разведочных работ. В зависимости от специфики решаемых геологических проблем в такое техническое сопровождение входят горные и буровые работы, геофизические и гидрогеологические исследования, каротаж и т.д. Наиболее широко применяются буровые работы, которые являются основным техническим средством получения геологической информации как по ее объему, так и по качеству. Бурение скважсин в сравнении с проведением горноразведочных выработок обладает более высокой производительностью, значительно меньщей стоимостью и удовлетворительным качеством получаемой информации.
\end{abstract}

Ключевые слова: месторождение полезных ископаемых, поиски и разведка, геологический разрез, метод скважинного подземного выщелачивания (ПСВ), технологические скважины, закачные и откачные скважины, продуктивные (рудные) горизонты

\section{ПАЙДАЛЫ ҚАЗБАЛАРДЫ ӨНДІРУДІН ҰНҒЫМАЛЫҚ ӘДІСТЕРІ}

Аңдатпа: Ғылыми мақалада жаңуа кен орындарын, пайдалы құзбаларды іздеу және олардың өнеркәсіптік маңызын анықтау міндеттері ұсынылган. Аталван міндеттерді жовары сапалы және қысққа мерзімде орындау үшін геологиялық-барлау жұмыстарына тиісті техникалық ққолдау құжет. Шемілетін геологиялық проблемалардың ерекшелігіне байланысты мұндай техникальқ сүйемелдеуге тау-кен және бұргылау жұмыстары, геофизикалық және гидрогеологиялық зерттеулер, каротаж және т.б. кіреді. Бұргылау жұмыстары кеңінен құолданылады, олар геологиялық ақпаратты оның көлемі мен сапасы бойынша алудың негізгі техникалық құралы болып табылады. Ұнздымаларды бұрzылау тау-кен барлау жұмыстарын жүргізумен салыстырzанда, өнімділігінің бірнеше есе жовары және едәуір құны төмен, ал алынатын ақ̧параттың сапасының қ̧анаваттанарлывын байқаймыз.

Түйінді сөздер: пайдалы қุазбалар кен орны, іздеу және барлау, геологиялық құима, ұнъымалық жерасты шаймалау әдісі (ҰЖШ), технологиялық ұнзыммалар, айдау және айдау ұнгымалары, өнімді (кенді) қъабаттар

\section{BOREHOLE MINING METHODS OF MINERALS}

Abstract: The scientific article offers problems of searching for new deposits, minerals and identifying their industrial significance. To perform these tasks with high quality and in a short time, appropriate technical support for geological exploration is required. Depending on the specifics of the geological problems to be solved, such technical support includes mining and drilling operations, geophysical and hydrogeological studies, logging, etc. The most widely used drilling operations are the main technical means of obtaining geological information both in terms of its volume and quality. Drilling wells in comparison with conducting 
mining operations has a much higher productivity, significantly lower cost and satisfactory quality of the information received.

Key words: mineral deposits, prospecting and exploration, geological section, underground leaching method, technological wells, injection and pumping wells, productive (ore) horizons

В результате проведения комплекса поисковых и разведочных работ производится разведка месторождения того или иного вида полезного ископаемого.

Месторождение (полезного ископаемого) - это природное скопление (место скопления, местонахождение) минерального вещества (полезного ископаемого) на поверхности или в недрах Земли. В результате тех или иных геологических процессов по количеству, качеству и горнотехническим условиям разработки пригодны для промышленной разработки с положительным экономическим эффектом.

Месторождения могут заключать:

- газовые (горючие газы углеводородного состава и негорючие газы - гелий, неон, аргон, криптон);

- жидкие (нефть и подземные воды);

- твёрдые (ценные элементы, кристаллы, минералы, горные породы) полезные ископаемые.

По промышленному использованию месторождения разделяются на:

- рудные или металлические (месторождения черных, цветных, легких, редких, благородных и радиоактивных металлов);

- нерудные (неметаллические) (месторождения химического, агрономического, металлургического, технического и строительного сырья);

- горючие (месторождения нефти, горючих газов, углей, горючих сланцев и торфа);

- гидроминеральные (подземные и поверхностные бытовые, технические, бальнеологические и минеральные воды).

Все минеральные ресурсы, как твердые, так и жидкие, и газообразные на нашей планете располагаются неравномерно и находятся либо на поверхности, либо глубоко под землей, и в зависимости от их мест размеще- ния и залегания для их добычи используют тот или иной способ.

Наиболее распространенными способами добычи природных ресурсов являются:

- открытый либо карьерный способ;

- закрытый либо подземный или шахтный способ;

- комбинированный либо открыто-подземный способ;

- геотехнологический либо скважинный способ;

- дражный способ.

Скважинная гидродобыча (СГД) - метод подземной добычи твердых полезных ископаемых, основанный на приведении полезного ископаемого на месте залегания в подвижное состояние путем гидромеханического воздействия и выдачи его в виде гидросмеси на поверхность.

Скважинный способ добычи получил наибольшее распространение, т.к. является малозатратным, менее трудоёмким и вследствие этого наиболее рентабельным. Скважинным способом добычи производится добыча газовых, жидких и твердых полезных ископаемых. Наибольший объем добычи скважинным методом через пробуренные скважины производится добыча и разработка месторождений углеводородного сырья - нефти, газа, газоконденсата и т.п., а также подземных вод.

На сегодняшний день способ подземного скважинного выщелачивания является самым современным, экологически безопасным и экономически выгодным методом добычи природного урана.

В отличие от традиционного шахтного способа добычи путем извлечения руды из недр, ее дробления и обработки, в технологии подземного скважинного выщелачивания (ПСВ), также известной как добыча растворением, руда остается на месте залегания, 
и через нее прокачиваются жидкости для выщелачивания минералов из руды. Благодаря применению данной технологии почвенный покров почти не нарушается, не образуется хвостов и пустой породы, и полностью отсутствует рудная пыль.

Существующие источники энергии уголь, газ, нефть - постепенно истощаются. Альтернативным источником энергии становится энергия атома. Основным сырьем энергии атома является уран, извлекаемый из руд. Природные ресурсы урана также не безграничны и поэтому более полное их использование весьма актуально. Важной особенностью ядерной энергетики является сравнительно малая величина себестоимости топливной составляющей в цене производимой энергии, что обуславливает её конкурентоспособность по сравнению с энергетикой, использующей другие полезные ископаемые, применяемые в качестве энергоносителей. Топливная составляющая в себестоимости 1 кВт/часа электроэнергии, производимой, например, АЭС России, в 8 раз меньше по сравнению с лучшими показателями ТЭЦ. При условии безаварийной работы атомные электростанции являются экологически более предпочтительными, так как не выделяют углекислоту в атмосферу.

Методы добычи урана через горношахтные выработки ограничены, так как современная техника не позволяет технически, технологически и экономически рентабельно вовлекать в эксплуатацию: бедные руды, руды, залегающие на значительных глубинах, руды, залегающие в сложных горно-геологических условиях.

На сегодняшний день Казахстан по добыче, а также по разведанным запасам урана, пригодным для отработки способом подземного выщелачивания является мировым лидером.

Способ добычи урана методом подземного скважинного выщелачивания (ПСВ) был впервые использован в 1960-х годах на месторождениях Узбекистана, и составляет 50\% мирового производства урана в 2020 году. Метод ПСВ, в сравнении с традиционными способами, обеспечивает более низкую стоимость добычи, оказывает меньшее негативное влияние на окружающую среду и обеспечивает высокие показатели в сфере безопасности производства и охраны труда.

Благоприятные геологические условия Республики Казахстан, подходящие для добычи методом ПСВ, обеспечивают АО «НАК «Казатомпром» уникальное конкурентное преимущество. 100\% добычи урана АО «НАК «Казатомпром» осуществляется методом ПСВ.

АО «НАК «Казатомпром» является лидером в добыче урана методом ПСВ с производительностью 12,1 тыс. тонн ( 20\% мировой добычи урана в 2017 году), значительно превосходя своих основных конкурентов.

Подземное выщелачивание - прогрессивный метод, широко применяемый в Республике Казахстан, при добыче урана. Этот метод прошел все стадии исследований, разработки и промышленного внедрения на гидрогенных месторождениях ШуСарысуской и Сыр-Дарьинской урановых провинциях, залегающих в проницаемых осадочных породах депрессионных зон земной коры, где вскрытие и подготовка рудных тел и добыча урана осуществляются через буровые скважины.

Скважины подземного выщелачивания - скважины, предназначенные для вскрытия рудных тел и извлечения продуктивных растворов из недр. По своему назначению они подразделяются на технологические (закачные и откачные), наблюдательные, контрольные и специальные.

Скважины закачные - скважины, через которые в рудные тела подается рабочий раствор. Скважины откачные - скважины, через которые из продуктивного горизонта выдается на поверхность продуктивный раствор. В практике подземного выщелачивания закачные и откачные скважины могут меняться назначением.

Скважины наблюдательные - предназначены для постоянного или периодического наблюдения за процессом подземного выще- 
лачивания или режимом подземных вод (растворов) в выщелачиваемой горной массе.

Скважины контрольные - используются для вскрытия в заданном месте отрабатываемого рудного тела с целью определения.

При разработке этого типа месторождений урана весь цикл работ по добыче состоит из следующих процессов:

1. Бурение и оборудование технологических скважин.

2. Выщелачивание урана из рудных тел, т.е. перевод металла в раствор.

3. Откачка из недр и транспортировка технологических растворов.

4. Сорбция урана из продуктивных растворов и десорбция.

5. Экстракция и реэкстракция.

Преимущество метода ПВ заключается не только в значительном сокращении переделов, но и в том, что процессы добычи приобрели совершенно иную качественную характеристику в части затрат человеческого труда, орудий труда и средств производства.

При использовании этого метода отпадает необходимость строительства дорогостоящих рудников или карьеров, а также гидрометаллургических заводов, расходования многих материалов; сокращается численность работающих на строительстве и при эксплуатации месторождений; увеличиваются природные сырьевые ресурсы в результате разработки месторождений с бедным и убогим содержанием урана в руде, залегающих в сложных гидрогеологических условиях (их разработка традиционными способами экономически невыгодна).

Подземное выщелачивание (ПСВ) через пробуренные скважины химическими реагентами открывает широкие возможности для комплексного использования урановых руд, что позволяет рентабельнее использовать более бедные руды. Основным видом работ при подготовке месторождений урана для добычи урана методом ПСВ, определяющим объемы и качество добываемого урана, являются горно-подготовительные работы (ГПР) - бурение технологических скважин. Для добычи уранового сырья уранодобывающие ком- пании применяют наиболее рентабельный и экологически безопасный метод подземного скважинного выщелачивания (ПСВ). Добыча уранового сырья производится через пробуренные технологические (закачные и откачные) скважины.

Подземное скважинное выщелачивание (ПСВ) - это сложный физико-химический процесс, протекающий в геологической среде. Динамика этого процесса, его особенности определяются фациально-литологическими свойствами рудовмещающих горизонтов, руд и всего разреза в целом. При подземном выщелачивании проницаемых рудных тел месторождение вскрывается системой технологических скважин, располагаемых (в плане) рядами, многоугольниками, кольцами. В закачные скважины подают растворитель, который, фильтруясь по пласту, выщелачивает полезные компоненты. Продуктивный раствор откачивается через другие (откачные) скважины.

Для добычи уранового сырья методом ПСВ по всей площади месторождения проводятся горно-подготовительные работы, включающие бурение скважин, различающихся своим назначением.

Технологические скважины, предназначенные для подачи в недра рабочих растворов - закачные (нагнетательные) и для подъема технологических растворов на поверхность - откачные (разгрузочные), обеспечивают выполнение ещё одной важнейшей функции - через них осуществляется регулирование гидродинамического режима в продуктивном пласте, определяющего пути и скорости фильтрации рабочих растворов.

Кроме этого, на всех месторождениях урана также бурят гидрогеологические, барражные, контрольные, эколого-мониторинговые и наблюдательные скважины.

В процессе ПСВ буровые скважины выполняют широкий комплекс различного рода функций:

- геологическая разведка;

- вскрытие и подготовка запасов;

- отработка запасов; 
- управление движением технологических растворов в продуктивной толще путем создания в эксплуатационном блоке гидродинамической обстановки, обеспечивающей формирование такой структуры фильтрационного потока растворов, которая в максимальной степени благоприятствовала бы течению физико-химических процессов ПСВ;

- контроль количества и качества откачиваемых и закачиваемых растворов, создание противофильтрационных завес; контроль гидродинамических и физико-химических параметров ведения процесса ПСВ;

- контроль полноты извлечения урана из руд; охрана окружающей среды от возможного физико-химического загрязнения.

Геологический разрез поисковых площадей и месторождений урана представлен горными породами осадочного комплекса - от четвертичных, неогеновых, палеогеновых до меловых отложений. В литологическом плане разрез представлен «наносами» - горизонтально или пологозалегающими перемежающимися осадочными толщами - песками разной зернистости, глинами, с прослоями алевритов, алевролитов, песчаников, гипсов, известняков и других прослоев осадочных горных пород. Горные породы месторождений относятся к II-VII категории по буримости, средняя категория пород по буримости IV.

Месторождения урана Шу-Сарысуйской и Сырдарьинской уранорудных провинций относятся к гидрогенному пластово-инфильтрационному типу. Продуктивные (рудные) горизонты чаще всего слагаются неоднородными песчаными толщами от тонкозернис- тых, среднезернистых до крупнозернистых песков, с включением глинистых частиц и карбонатных обломков коренных горных пород (известняки, алевролиты, алевриты, гипсы и т.п.). Все продуктивные горизонты повсеместно обводнены. Продуктивные горизонты имеют горизонтальное или полого наклонное залегание. С учетом пространственного расположения продуктивных горизонтов все скважины бурятся вертикально. Разведочные скважины бурятся вертикально с целью определения истинной мощности рудных горизонтов, что очень важно для точного подсчета запасов руды в продуктивном горизонте и в целом на месторождении. Соответственно, технологические скважины бурятся также вертикально, с целью вскрытия, подготовки и отработки запасов.

При отработке месторождений урана в Казахстане методом подземного скважинного выщелачивания (ПСВ) при проведении горно-подготовительных работ бурение технологических, эксплуатационно-разведочных, гидрогеологических, эколого-мониторинговых и других скважин в 2020 году производят 11 буровых компаний. Наибольший объем буровых работ до $80 \%$ производит АО «Волковгеология». ТОО СП «РусБурмаш» проводит буровые работы для 5 уранодобывающих предприятий (рис.1).

Таким образом, ТОО СП «РусБурмаш» на сегодняшний день производит буровые работы 28 буровыми агрегатами, ежегодно компания бурит порядка 1000000 погонных метров буровых скважин, а также планирует наращивать объемы буровых работ.

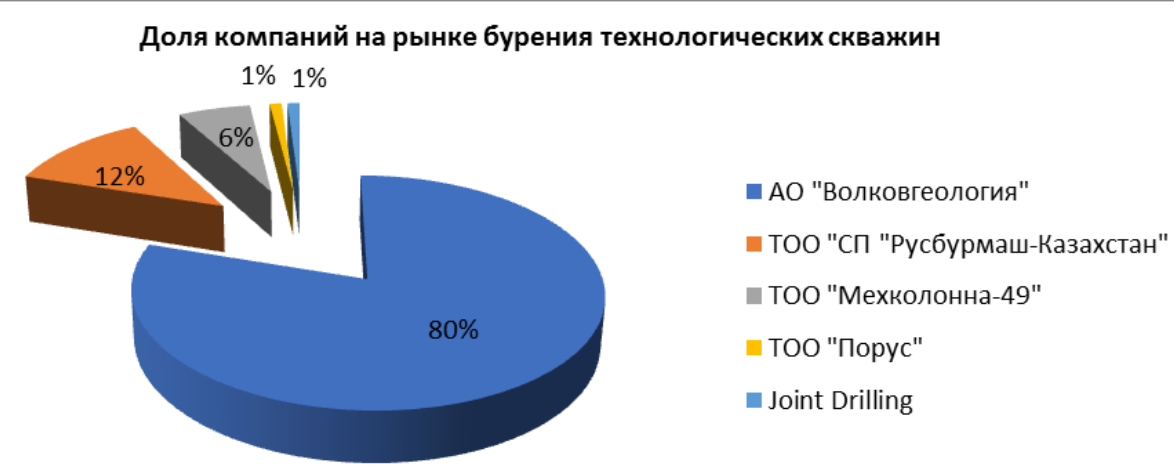

Рис. 1 - Доля компаний на рынке бурения технологических скважин 


\section{ЛИТЕРАТУРА}

1. Сушко С.М. Технология и техника при строительстве геотехнологических скважин для подземного выщелачивания урана. - Алматы: Волковгеология, 2007. - 259 с.

2. Сушко С.М., Асанов Н.С., Карманов Т.Д., Калиев Б.З., Кадыров Ж.Н., Кочетков А.В. Метод гидроизоляции затрубного пространства при сооружении геотехнологических скважин для подземного выщелачивания продуктивного горизонта//Международный журнал экспериментального образования. - 2013. - №11-2. - С.118-122.

3. Мамилов В.А., Петров Р.П., Шушания Г.Р., Баташов Б.Г., Веселова Л.Н. Добыча урана методом подземного выщелачивания. - Москва, 1980 г. - 248 с. 